\title{
Communicative language teaching to develop the writing skill in EFL
}

\section{El método comunicativo para desarrollar la escritura en EFL}

\author{
Doris Alexandra Chuquimarca Once. ${ }^{1}$
}

\begin{abstract}
.
DOI: https://doi.org/10.33262/concienciadigital.v3i3.1.1388

In the present research, the Communicative Language Teaching Method (CLT) contributed in a practical way in the teaching - learning process due to it helped to improve the English level in the writing skill of the students of the Language Center at "Escuela Superior Politécnica de Chimborazo." Techniques based on CLT significantly reduced mistakes in writing and let students write texts in a clearly way. Thus, students were able to use English to write academic reports, emails, letters, and notes in English in a better way. Also, thanks to the interaction that students had through the CLT Method, the university got some benefits such as better teaching performance, writing production and academic development. The triangulation of methods, techniques and instruments was used to obtain accurate data and intervene in the writing process. The empirical method let the researcher-teacher collect information from the students' performance in the English class through an observation guide. Also, the Analytical Method, a Cambridge test KET, and a content analysis table (Cambridge writing rubric) were used in the research, to determine the students' most common writing mistakes. The Experimental Method was used to contrast the results obtained in a pre and post-tests. The intervention was directly applied in the experimental group of 24 students to be contrasted with the control group. A descriptive and inferential statistical analysis served to demonstrate the possible change in writing skill after the intervention of the researcher. All these results demonstrated the positive impact of the project on the improvement of the writing skill.
\end{abstract}

Key words: CLT, writing, English, learning, improvement.

${ }^{1}$ Escuela Superior Politécnica de Chimborazo, Riobamba, Ecuador, doris.chuquimarca@espoch.edu.ec 


\section{Resumen}

En la presente investigación, el Método Comunicativo (CLT) contribuyó de manera práctica en el proceso de enseñanza - aprendizaje al mejoramiento del nivel de escritura en inglés de los estudiantes del Centro de Idiomas de la Escuela Superior Politécnica de Chimborazo ". Las técnicas basadas en CLT redujeron significativamente los errores en escritura y permitieron a los estudiantes escribir textos de manera clara. Por lo tanto, los estudiantes pudieron usar el inglés para escribir informes académicos, notas, correos electrónicos, cartas y otro tipo de trabajos académico en inglés de mejor manera. Además, gracias a la interacción que los estudiantes tuvieron a través del Método CLT, la universidad obtuvo beneficios, como un mejor rendimiento docente, producción de escritura y desarrollo académico. La triangulación de métodos, técnicas e instrumentos se utilizó para obtener datos precisos e intervenir en el proceso de escritura. El método empírico permitió al investigador-maestro recopilar información del desempeño de los estudiantes en la clase de inglés a través de una guía de observación. Además, el método analítico, una prueba KET y una tabla de análisis de contenido (rubrica de Cambridge) se utilizaron en la investigación para determinar los errores de escritura más comunes de los estudiantes. El Método Experimental se utilizó para contrastar los resultados obtenidos en una prueba previa y posterior. La intervención se aplicó directamente en el grupo experimental de 24 estudiantes para contrastar con el grupo control. Un análisis estadístico descriptivo e inferencial sirvió para demostrar el posible cambio en la habilidad de escritura después de la intervención del investigador. Todos estos resultados demostraron el impacto positivo del proyecto en la mejora de la habilidad de escritura.

Palabras Clave: CLT, escritura, inglés, aprendizaje, mejoramiento.

\section{Introduction}

English is considered as the most important language around the world. A great number of bibliographical materials is written in this language. Based on this reality, students need to know how to write in English for intellectual production. The need for a method to develop the English writing skills is unquestionable. In several countries around the world there are studies that demonstrate how methods to teach the English language have improved the result in the teaching learning process. One of these relevant methods is the Communicative Language Teaching (CLT) which can affect the development of writing in a foreign language in the construction of texts for academic, scientific, economic, cultural, and social purposes. For the construction of these texts, effective writing development techniques are needed, not only as a set of words and rules but also as a determining element for the construction of meanings and interaction. This idea is reaffirmed by Bowkett, (2014)who argues that the analysis and teaching of grammar in L2 (foreign language) is not enough. It is necessary to change this orthodox practice for extensive practice of writing in 
non-native student. CLT improves the productive writing through interaction in community. It is important to arouse interest and help learners to increase their writing production. The need for improvement writing skills is evident in English students of the Language Center at ESPOCH. Writing must be improved in communicative achievement, organization, and language. These aspects were observed and evaluated in everyday practice in the classroom.

Writing is taught from the earliest ages, not only as an opportunity to learn, to know, to create, to access other ways of life, but as Grabe \& Kaplan, (2014) mentions, we must not lose sight of the child's need to train in reading and writing to understand what surrounds him. Writing is for life itself, the illiterate is condemned to not understand the writing of posters, maps, important information for procedures, to interact with this world of letters. From this point of view Roe, S. Roe \& Ouden, (2018) mentions that this process does not occur spontaneously, but occurs at a certain moment, it obeys stages such as preparation, introduction, systematic teaching and finally reading and writing as a learning tool. Julián \& Silvia (2014) mentions writing as a problem in the educational system in all parts of the world and at all levels. Rahma (2014) explains that many times writing is limited to memorization, inconsistency and does not develop logic and creativity. At a higher level, the problem is repeated not only in university students but also in teachers, as mentioned by Wallbank, (2018)

This book discusses the role that integrated science and higher education policies may play in further democratizing and promoting social-economic development in Latin America. It suggests that such democratizing and development may be achieved in two complementary ways: i) broadening the access to knowledge through formal learning processes of higher education, and ii) promoting the advanced qualification of people while strengthening research institutions. The book shows how this entails a complex process of policy integration, with an emphasis on human resources and institutional issues combined in processes of technical change. It discusses in detail the three main challenges that most Latin American countries face in a globalized age, based on knowledge and ever-evolving learning processes. These challenges are the need to broaden the access to higher education; to make this access more socially balanced; and to recover from a long gap in investing in knowledge production and dissemination. This book treats these issues from a variety of conceptual and methodological perspectives that present a contribution to the field of science policy and higher education studies, and inform policymakers in Latin America Horta et al. (2015) indicates that Ecuador has relatively low level of scientific production in the world, along with some Latin American countries. This is due to various factors, such as bibliography, financial and human resources. The most important factor is undoubtedly the human factor, who produce scientific knowledge, teachers, students, public and private companies. This project is focused primarily on students, future professionals who learn English, who develop the writing process in this language. Alamargot \& Chanquoy, (2012) present the existence of three processes in writing (elaboration, expression, revision) and the possibility of intervening in the stages of this process. To intervene in the writing process is necessary to know the appropriate methodology. 
Some researchers agree that CLT is a useful tool for developing communication skills. Richards et al., (2001) says the development of writing skill let the learners to frame a language . LarsenFreeman (2000) considers that the application of efficient methods can develop writing, he agrees with Richards, (2006) who declares that CLT improves communication thanks to the combination of several didactic elements. The factors involved in this process are: study plan, materials, techniques and essential activities to put the communication skills into practice.

Based on these precepts, the fundamental idea was to motivate the teacher so that they, in turn, would be the guide for their students. A joint work was carried out in the classroom, both students and teachers, trying to go beyond theoretical contributions, the idea was to develop a network of communicative and intellectual interaction that allows the permanent development of the English language, knowledge and social interaction.

The development of writing skills is essential in the process of teaching and learning English; A teacher cannot improve the students' level of English without this skill. English learners use this skill when they do research reports, when they present class work, or when they interact via email or text message. Teachers and researchers have worked to develop this skill by applying the Communicative Method. This study led to the hypothesis that the Communicative Language Teaching Method positively influences the writing development of ESPOCH students.

The influence of Communicative Language Teaching on the writing process in the students of the ESPOCH Language Center was analyzed. The essential inspiration of this project was to fundamentally rise above in the instructive, logical, and social viewpoints. Adding to the scholarly improvement of ESPOCH understudies, with methods dependent on CLT to improve these abilities. Writing correctly gave students the likelihood to perform better on tests, interface in the scholastic and scholarly world, and It was a significant apparatus in teaching practice. Based on the above, the teacher and researchers have worked to develop this skill by applying the teaching of the communicative method. Hinkel,( 2011) mentions that the combination of the CLT method with other resources helps improve the level of writing of people learning English

\section{Methodology}

The examination is quantitative-subjective, observational, diagnostic, trial, socio-instructive, bibliographic-narrative, field and correlational. It is quantitative-qualitative because it takes numerical and descriptive data, through the instruments applied to determine the reality to be examined. The association in the homeroom permitted to acquire helpful information to intervene in the problem in question, which is why this is an empirical and field investigation. Thorough analysis using the Cambridge KET writing rubric identifies this research as analytical. It is an experimental investigation because it contrasts data from a pre and a post test in a control group and an experimental group, it is socio-instructive on the grounds that it underpins the accomplishment of the goals of the National Plan "Toda una vida", which is to fortify the limits and capability of the citizenship. Besides, the utilization of solid sources to altogether investigate 
the factors, and the connection between CLT and writing exhibit that this is a bibliographic and correlational investigation.

In the analytical cycle, three sorts of examination were confirmed: illustrative, applied and contrastive, through graphic exploration the significant highlights of the issue were called attention to, the properties referring to it were detailed and finally the population trend based on writing test was described. . The research seeks the solution to the problem of low-level writing in the students of the ESPOCH Language Center, for this purpose, techniques based on CLT worked by the researcher were applied throughout the mentioned academic period. Finally the information was looked at by utilizing a pre-test and a post-test planned for measuring composing and exhibiting in quantitative terms the degree of composing improvement of thestudy group.

The development of a matrix served to operationalize the factors, and to plan a hypothetical structure in a deductive way to elaborate the state of the art, it also served to determine in hierarchical order the fundamental concepts of the variables, the dimensions and the indicators that allowed the elaboration of the instruments to know the level of students in writing.

Then the instruments for obtaining data from the writing pretest were developed, applied, and organized. CLT based techniques were applied to improve composing.

Introduction and correlation of measurable information dependent on the aftereffects of the instruments, content examination table, observation guide (rubric) and contrastive statistical analysis, in the pre and post test between the experimental group and the control group, this served to demonstrate

\section{Hypothesis formulation}

The hypotheses stablished are raised to be accepted or rejected according to the test results.

\section{Null Hypothesis}

The application of techniques using CLT will not improve the students' English composition of the ESPOCH Language Center

\section{Alternative Hypothesis}

The application of techniques using CLT will not improve the students' English composition of the ESPOCH Language Center

\section{Population and Sample.}

The population made up of the 48 students from the ESPOCH Language Center was the population for this research.

The sample of 24 students was picked thinking about the practicality of executing the project, the analyst filled in as an educator in the period and course referenced. It merits referencing that there is no university in the city that has a similar degree. The following is presented in the following tables. 
Population

\begin{tabular}{lll}
\hline Population & Frequency & Percentage \\
\hline Students & 48 & $100 \%$ \\
Total & 48 & $100 \%$ \\
\hline
\end{tabular}

Source: Direct research

Autor: Chuquimarca D. Ecuador, 2019

Sample

\begin{tabular}{lll}
\hline Sample & Frequency & Percentage \\
\hline Experimental group & 24 & $50 \%$ \\
Control group & 24 & $50 \%$ \\
Total & 48 & $100 \%$ \\
\hline
\end{tabular}

Source: Direct research

Author: Chuquimarca D. Ecuador, 2019

\section{Techniques and instruments.}

\section{Content analysis table}

To obtain quantitative data, a Cambridge KET test and a rubric were used as a table of content analysis that aimed to quantify the level of writing of the population and sample in a pre and posttest. The aspects evaluated in this instrument were Communicative achievement, organization, and language- This instrument allowed to have a clear perspective of the problem, to elaborate an intervention project and to establish the research hypotheses.

\section{Observation Guide}

The second instrument used was born in daily teaching practice, it was an adapted observation guide from (Chen, 2014) it was used on a monthly periodic basis, this instrument measured the way the CLT method was applied to the students' level of writing. This instrument served to investigate the underlying aspects of the Communicative Language Teaching Methods and how to improve it during its execution-

\section{Comparative statistical analysis}

The results obtained during the pre and posttest were descriptively and inferentially contrasted. These were analyzed with T-students and were used to contrast the results obtained in the experimental group and in the control group. 


\section{Results and discussion}

The study "Communicative Language Teaching to develop the writing skill in EFL" demonstrates the correlation between the CLT variable and the writing dependent variable. The triangulation of instruments demonstrated what was stated in the alternative hypothesis: "The application of techniques based on the CLT will improve students' writing level at ESPOCH Language Center." A diagnostic test is taken as a starting point. At first glance, in the post test after the application of techniques based on CLT, an improvement in the qualification of the students in the KET test is evident, that is, an increase in the level of writing in general in the instrument rubric from Cambridge. The increase of 1.2 in the experimental group while in the control group the improvement is just $0.6 \%$ points in the total grade for the course. This is not enough, the purely descriptive plane had to be transcended and we worked with a T-students test, the change between the pre and post test was statistically analyzed.

\section{Total KET test}

\begin{tabular}{|c|c|c|c|c|}
\hline KET test & $\begin{array}{l}\text { Pre-test control } \\
\text { group }\end{array}$ & $\begin{array}{l}\text { Post-test control } \\
\text { group }\end{array}$ & $\begin{array}{l}\text { Pre-test } \\
\text { Experimental } \\
\text { group }\end{array}$ & $\begin{array}{l}\text { Post-test } \\
\text { Experimental } \\
\text { group }\end{array}$ \\
\hline & 2,81 & 3,24 & 2,63 & 3,57 \\
\hline
\end{tabular}

Source: Direct research

Author: Chuquimarca D. Ecuador, 2019

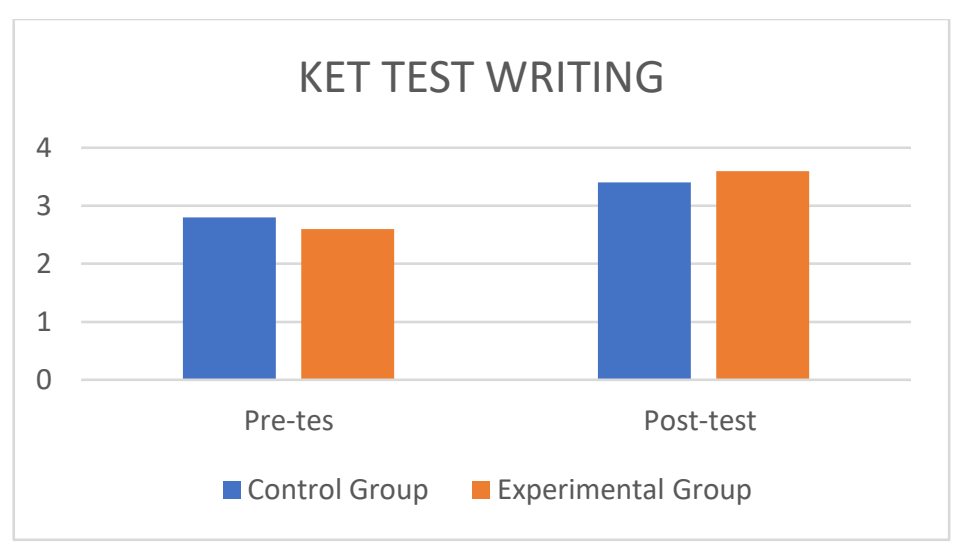

Source: Direct research

Author: Chuquimarca D. Ecuador, 2019

\section{Observation Guide}

The second instrument, the observation guide, which consisted of an observation guide modified by Chen (2014), shows a significant improvement in all aspects of the evaluation during the interaction of students with the teacher, in pair work, work group and individual student work 


\section{Observation Guide}

\begin{tabular}{|c|c|c|c|c|c|}
\hline \multicolumn{6}{|c|}{ GUÍA DE OBSERVACIÓN CLT } \\
\hline \multicolumn{2}{|c|}{ Evaluated aspects } & $\begin{array}{c}\text { Observation } \\
1\end{array}$ & $\begin{array}{c}\text { Observation } \\
2\end{array}$ & $\begin{array}{c}\text { Observation } \\
\mathbf{3}\end{array}$ & $\begin{array}{c}\text { Observation } \\
4\end{array}$ \\
\hline \multirow{4}{*}{ In teacher talk } & support & 3.8 & 3.9 & 4.1 & 4.1 \\
\hline & Questioning & 3.8 & 4.1 & 4.3 & 4.5 \\
\hline & $\begin{array}{l}\text { Talk } \\
\text { management }\end{array}$ & 3.3 & 3.5 & 4.3 & 4.5 \\
\hline & Topic & 3.6 & 4.0 & 4.2 & 4.4 \\
\hline \multirow{3}{*}{$\begin{array}{l}\text { In pair/group } \\
\text { work }\end{array}$} & Design & 4 & 4 & 4.5 & 4.5 \\
\hline & $\begin{array}{l}\text { Students' } \\
\text { behavior }\end{array}$ & 3 & 4 & 5 & 5 \\
\hline & Teacher strategy & 4 & 4 & 4.5 & 4.5 \\
\hline $\begin{array}{l}\text { Individual } \\
\text { work }\end{array}$ & Writing report & 3 & 3.2 & 3.4 & 3.9 \\
\hline
\end{tabular}

Source: Direct Research

Author: Modified from, Chen (2014)

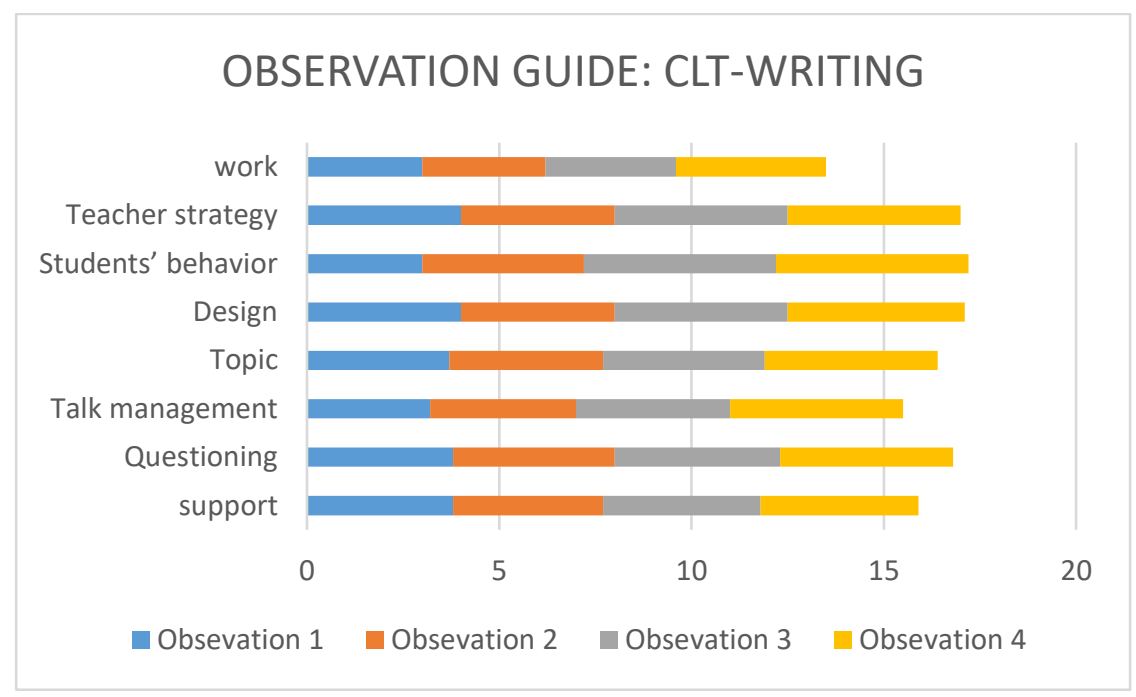

Source: Direct Research

Author: Modified from, Chen (2014)

The Observation Guide for Communicative Language Teaching was helpful in verifying errors in general English language development and in improving the problems studied in the KET rubric. 
After data collection, theorizing, applying CLT, and analysis of the data obtained, it was determined that students have improved their writing level. The CLT application has evolved with the evolution of writing skills in students from the ESPOCH Language Center. The results obtained in this instrument are positive in all aspects studied, especially emphasized in the results obtained in the writing of written reports of the students.

\section{Comparative statistical analysis}

In the following table it is possible to observe the variation of the results, in the pre and post test in the experimental an control group, this results were analyzed thought T-student to determine its validity with statistical data.

Result KET pre and post test

\begin{tabular}{|c|c|c|c|c|}
\hline \multicolumn{5}{|c|}{ KET TEST } \\
\hline \multicolumn{3}{|c|}{ Control group } & \multicolumn{2}{|c|}{ Experimental Group } \\
\hline Student & Pre-test & Pos-test & Pre-test & Pos-test \\
\hline $\mathrm{S} 1$ & 2 & 2 & 1 & 3 \\
\hline $\mathrm{S} 2$ & 3 & 4 & 2 & 3 \\
\hline S3 & 1 & 3 & 3 & 4 \\
\hline S4 & 3 & 3 & 3 & 3 \\
\hline S5 & 4 & 4 & 3 & 4 \\
\hline S6 & 2 & 2 & 2 & 2 \\
\hline S7 & 3 & 3 & 3 & 3 \\
\hline S8 & 3 & 3 & 2 & 3 \\
\hline S9 & 4 & 4 & 4 & 4 \\
\hline $\mathrm{S} 10$ & 3 & 3 & 3 & 3 \\
\hline S11 & 1 & 3 & 3 & 5 \\
\hline $\mathrm{S} 12$ & 3 & 3 & 2 & 3 \\
\hline S13 & 3 & 5 & 1 & 3 \\
\hline S14 & 4 & 4 & 4 & 4 \\
\hline S15 & 2 & 3 & 2 & 4 \\
\hline S16 & 2 & 2 & 2 & 3 \\
\hline S17 & 4 & 4 & 3 & 4 \\
\hline $\mathrm{S} 18$ & 3 & 3 & 3 & 4 \\
\hline S19 & 1 & 3 & 3 & 4 \\
\hline S20 & 3 & 3 & 3 & 4 \\
\hline $\mathrm{S} 21$ & 2 & 2 & 2 & 3 \\
\hline S22 & 3 & 3 & 1 & 3 \\
\hline S23 & 4 & 5 & 4 & 5 \\
\hline S24 & 3 & 3 & 3 & 4 \\
\hline Mean & 2,81 & 3,24 & 2,63 & 3,57 \\
\hline
\end{tabular}

Source: Direct Research 
ISSN: 2600-5859

Author: Modified from, Chen (2014)

Paired Samples Statistics

\begin{tabular}{llllll}
\hline & & Mean & N & Std. Deviation & Std. Error Mean \\
Pair 1 & Pre test & 2,750 & 24 &, 9441 &, 1927 \\
& Post Test & 3,208 & 24 &, 8330 &, 1700 \\
\hline
\end{tabular}

\section{Paired Samples Correlations}

\begin{tabular}{lllll}
\hline & & N & Correlation & Sig. \\
Pair 1 & Pre test \& Post Test & 24 &, 622 &, 001 \\
\hline
\end{tabular}

\section{Paired Samples Test}

Paired Differences

95\% Confidence

Interval of the

Difference

Mean Std. Deviation Std. Error Mean Lower

Pair 1 Pre test - Post Test $\quad-, 4583 \quad$,7790 $\quad, 1590 \quad$-,7873

\section{Paired Samples Test}

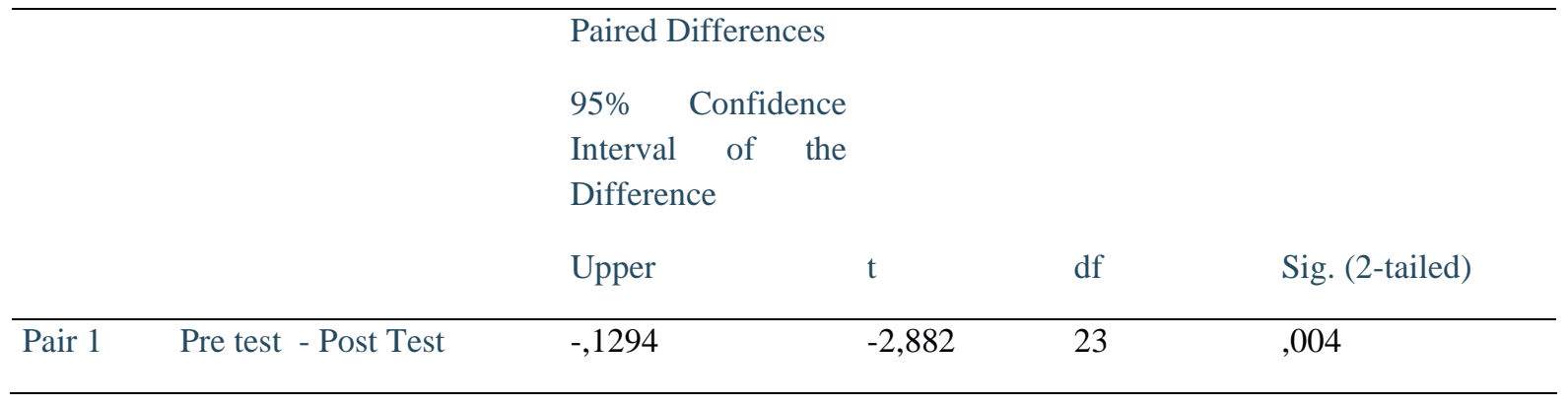

The study has a serious extent of legitimacy and dependability, the systematization in a subjective and quantitative plane, the show through factual tasks and the bibliographic help make this a demonstrated project. Universally tried instruments were utilized to complete this subjective and quantitative examination. The instruments created by the researcher were evaluated by peer researchers with a long history, with publications at national and international level. 
If writing is studied as a complex process that integrates symbols for the production of academic and scientific texts, in order to disseminate knowledge, then it is necessary to analyze it carefully, Sadeghi, (2014) mentions that writing is an intellectual process that involves social interaction with the community, is a way of making known to the world ideas about social reality, of examining through the texts the actions of individuals and the masses to present readers with a perspective of the context they study, also mentions that this process is not restricted to any language, but extends to all languages and genres. I have taken the starting point for the implementation of the CLT method to better this skill.

Research by Renandya \& Widodo, (2016) mentions the blend of the CLT technique and mechanical assets, can help improve the degree of composing and language learned in general. The impact of this technique on the improvement of composing capacity and its significance for learning English is delayed in the classroom, Savignon, (2008) investigated the application of CLTbased techniques for high school students with very good results. VYAS \& PATEL, (2015) explains that the proper application of this method significantly improves communication skills. (Renandya \& Widodo, 2016b)share this idea, The impact of these set of techniques on the improvement of composing capacity and its significance for learning the development of communication skills. Finally, Hall \& Hewings (2013)argues that the basic principles of CLT were that language and communication skills should not be treated in isolation.

But writing is not merely social, Mayer \& Alexander, (2016)mention the intellectual operations that an individual carries out when writing a text are sophisticated. The authors define the action of writing as "the set of distinctive thought processes organized or orchestrated by the writer during the act of composition." Hence, it is possible to agree with Minto, (2009) that "the students' writings are not intended to transmit knowledge, but rather to demonstrate that the same knowledge has been acquired. Torode, (2016) supports the idea that writing is a social practice that implies a recursive process that aims to guide the achievement of a final product.

The role of the CLT method, unlike traditional methods, is undoubtedly to carry out the teaching process in which students are considered active participants, this allows students to structure their ideas and translate them into writing. Creativity, will, imagination, and well-being are positive characteristics of this evolutionary method. McDonough \& Shaw, (2012) mentions that the CLT method are evolutionary that allow both development of knowledge of languages and content and that in turn allows social interaction.

Vongxay (2013) raise the need for the implementation of a curriculum based on Communicative Language teaching. This will allow writing to be developed both intellectually and socially. However, the authors argue that teachers should cease to be the center of effective educational plan execution. There is no doubt about the impact the educator has on the development, application, and change of methods and on achieving results in communication skills. However, G. Hall, (2016) states that the application of a CLT-based curriculum requires complete flexibility on the part of teachers. Activities that require effective interaction, that is, communication, are required. The teacher in this way allows students to acquire knowledge while developing language. As a product 
of this interaction, it is possible to borrow texts written by the students in which they demonstrate the acquisition of language. Writing as mentioned is a complex process that serves to produce texts, but can also develop logical and critical thinking to present readers with a perspective of the context they study, this process is not restricted to any language, but extends to all languages and genres. It is necessary to understand writing as a process that is carried out in several logical stages and therefore the need for a method.

To synthesize these ideas, Torode, (2016) agrees that writing is a chain of objectives that are presented in subjects and in objects immersed in in this process. Between the subjects, teacher and students and methodology applied for teaching. In this way, the need for a method that allows generating a strategic plan to produce texts becomes imperative. CLT is constantly restructuring the objectives throughout the writing form to critical and social entities that transmit structured thoughts.

\section{Conclusions}

- The improvement of the study permitted the English learners of the ESPOCH Language Center to be given an instrument to create writing in the English language. Imaginative methodological strategies were connected to this skill. The use of the CLT technique permitted to intercede in the creative cycle at all stages: pre-writing, association, writing and modifying. The last stage was especially intervened, but the applied techniques contemplate reading, prior organization of ideas and preparation of drafts by students as homework; notwithstanding, the viewpoint that was chipped away at in detail was altering, which comprised of remedying composing mistakes. Along these lines, the scholarly composition of the contemplated test was improved quantitatively and subjectively, as indicated by the KET rubric, the understudies' evaluation was expanded by 1.2 normal in the last grade of the experimental group, this is proportionate to $25 \%$ of the evaluation . It merits referencing that the item assessed by this rubric are: Communicative achievement, organization language. The outcomes acquired were shown in measurable terms. Through the observation guide, the development of the communicative method and the development of the writing skill were followed up. The academic effect is unmistakably proven, which shows the adjustment in the degree of cognitive level and, the improvement of composing, a perspective that encourages composed correspondence, simultaneously it can produce reliable texts.

\section{Bibliographic References}

Alamargot, D., \& Chanquoy, L. (2012). Through the Models of Writing. Springer Science \& Business Media.

Bowkett, S. (2014). A Creative Approach to Teaching Writing. Bloomsbury Publishing. 
Chen, Y.-M. (2014). Observations on Teachers' Knowledge Growth in the Communicative Approach in Taiwanese EFL Classes. US-China Education Review A, 4, 621-639.

Grabe, W., \& Kaplan, R. B. (2014). Theory and Practice of Writing: An Applied Linguistic Perspective. Routledge.

Hall, D., \& Hewings, A. (2013). Innovation in English Language Teaching: A Reader. Routledge. Hall, G. (2016). The Routledge Handbook of English Language Teaching. Routledge.

Hinkel, E. (2011). Handbook of Research in Second Language Teaching and Learning. Routledge.

Horta, H., Heitor, M., \& Salmi, J. (2015). Trends and Challenges in Science and Higher Education: Building Capacity in Latin America. Springer.

Julián, G., \& Silvia, S. (2014). Adolescentes y problemas de aprendizaje. Grupo Planeta Spain.

Larsen-Freeman, D. (2000). Techniques and Principles in Language Teaching. Oxford University Press.

Mayer, R. E., \& Alexander, P. A. (2016). Handbook of Research on Learning and Instruction. Taylor \& Francis.

McDonough, J., \& Shaw, C. (2012). Materials and Methods in ELT. John Wiley \& Sons.

Minto, B. (2009). The Pyramid Principle: Logic in Writing and Thinking. Financial Times Prentice Hall.

Rahma, A.-M. (2014). Methodologies for Effective Writing Instruction in EFL and ESL Classrooms. IGI Global.

Renandya, W. A., \& Widodo, H. P. (2016a). English Language Teaching Today: Linking Theory and Practice. Springer.

Renandya, W. A., \& Widodo, H. P. (2016b). English Language Teaching Today: Linking Theory and Practice. Springer.

Richards, J. C. (2006). Communicative Language Teaching Today. Cambridge University Press.

Richards, J. C., Richards, J. C., \& Rodgers, T. S. (2001). Approaches and Methods in Language Teaching. Cambridge University Press.

Roe, S. C., \& Ouden, P. H. den. (2018). Academic Writing, Third Edition: The Complete Guide. Canadian Scholars.

Sadeghi, S. (2014). The Role of Corrective Feedback in Writing Improvement. A Case of Iranian EFL Learners. GRIN Verlag.

Savignon, S. J. (2008). Interpreting Communicative Language Teaching: Contexts and Concerns in Teacher Education. Yale University Press.

Torode, et al. (2016). Text and talk as social practice: Discourse difference and division in speech and writing. Walter de Gruyter GmbH \& Co KG.

Vongxay, H. (2013). The Implementation of Communicative Language Teaching (CLT) in an English Department in a Lao Higher Educational Institution: A Case Study. A Thesis Submitted in Partial Fulfilment of the Requirements for the Degree of Master of Education, Unitec Institute of Technology, New Zealand. Unitec Institute of Technology.

VYAS, M. A., \& PATEL, Y. L. (2015). TEACHING ENGLISH AS A SECOND LANGUAGE, Second Edition: A NEW PEDAGOGY FOR A NEW CENTURY. PHI Learning Pvt. Ltd. 
ISSN: 2600-5859

Wallbank, A. J. (2018). Academic Writing and Dyslexia: A Visual Guide to Writing at University. Routledge.

PARA CITAR EL ARTÍCULO INDEXADO.

Chuquimarca Once, D. A. (2020). Communicative language teaching to develop the writing skill in EFL . C ConcienciaDigital, $\quad 3(3.1), \quad$ 275-288. https://doi.org/10.33262/concienciadigital.v3i3.1.1388

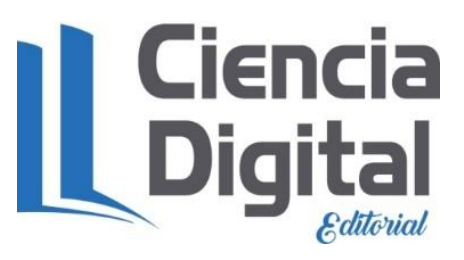

El artículo que se publica es de exclusiva responsabilidad de los autores y no necesariamente reflejan el pensamiento de la Revista Conciencia Digital.

El artículo queda en propiedad de la revista y, por tanto, su publicación parcial y/o total en otro medio tiene que ser autorizado por el director de la Revista Conciencia Digital.

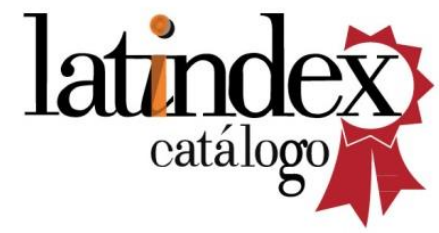

